ORIGINAL ARTICLE

\title{
Determination of Involvement and Life Satisfaction Levels for Recreational Activities of Individuals who are Members of Fitness Centers
}

\author{
MUSTAFA CAN KOÇ${ }^{1}$, AYŞE ASLI YÜZGENÇ² \\ ${ }^{1}$ Mersin University, Faculty of Sports Sciences, Department of Recreation, Mersin/ TURKEY. \\ ${ }^{2}$ Kastamonu University, Faculty of Sports Sciences, Department of Sport Management, Kastamonu/TURKEY. \\ Correspondence to Dr. Mustafa Can KOÇ, Email. mckoc@mersin.edu.tr
}

\begin{abstract}
Background: It can be thought that it is possible to define an individual's motivation and interest in a product or activity, the excitement of doing that job, as the concept of involvement.

Aim: The aim of this research is to determine the involvement and life satisfaction levels for the recreational activities of individuals who are members of fitness centers.

Methods: As a data collection tool in the research, Leisure Time Involvement Scale (LIS) developed by Kyle et al. (2007), whose validity and reliability for Turkish culture was made by Gürbüz et al. (2015), and Life Satisfaction Scale (LSS) developed by Diener et al., (1985) and adapted to Turkish culture by Köker (1991) were used. The population of the research consisted of private sports and fitness center users in Kastamonu, Samsun and Hatay provinces. The sample of the study consisted of 450 people (55\% Female, $45 \%$ Male) who are members of private sports and fitness centers in Kastamonu, Samsun and Hatay provinces and were selected by purposive sampling method. Descriptive statistical methods (percentage, frequency, mean, standard deviation), $T$ test, oneway analysis of variance ANOVA and pearson correlation test were used to analyze the data in the study.

Results: According to the findings of the study, while there was a significant difference in the variables of age group, education level, frequency of use of the sports center, and hours spent daily in the sports center in the leisure time involvement scale, no significant difference was found in the gender variable. In the life satisfaction scale, while there was a significant difference in the variables of gender, education and weekly usage frequency, no significant difference was found in the age group and the daily hours spent in the sports center.

Conclusion: In conclusion, the attractiveness factor has the strongest effect on individuals' leisure time involvement. In addition, it was determined that the participants' life satisfaction was high and there was a low and positive relationship between life satisfaction and leisure time involvement.

Keywords: Fitness centers, Recreational activity, Involvement, Life satisfaction.
\end{abstract}

\section{INTRODUCTION}

Various definitions of the concept of time have been made in many areas from the early ages up to now. Tezcan (1982) defines time as "a part of human life that cannot be repeated for a long or short period of time, has a definite beginning and ending, and can be measured in hours". Time is the moment which the individual is in and feels. It is possible to interpret the irreversible, unrepeatable, unpurchaseable and unstorable marching moments within the concept of time. The concept of time is divided into two as working time (work-related time) and non-working time (free time).

Leisure and leisure activities are the times when people can express themselves, have fun, relax, rest, develop in many ways and improve their social adaptability ${ }^{44}$. Leisure is defined as the time excluding obligatory occupations such as sleeping, eating, going to work, doing housework and personal care. People do various activities to redeem their free time and choose activities that they are happy with and enjoy. And for these activities, they prefer open and closed areas. That our research group consists of individuals who are members of sports centers is an example of what has been said and expresses the importance of the study. And in the light of all this information, it is thought that the concept of leisure involvement has emerged.

"It is possible to define involvement as the personal importance or interest shown towards the stimulus in a special situation" 41 . It can be thought that it is possible to define an individual's motivation and interest in a product or activity, the excitement of doing that job, as the concept of involvement. The English word "Involvement" has been translated into Turkish as "ilgilenim"30, "ilginlik"37 or "katılım"16. Involvement was first created by Krugman's research in marketing in 1966. In his research, Krugman expresses involvement as the person's 13 clues of making a voluntary connection or the number of connections of individual references in a minute between the content of a persuasive stimulus and the content of one's own life ${ }^{26}$. In general, involvement can be expressed as individual preference or the attitude of having a desire for any activity, and the satisfaction, pleasure and excitement obtained from it ${ }^{42}$. Involvement is a phenomenon not only mostly expressed in the literature as consumer characteristics, but also has managed to create supporters among leisure and recreation researchers in the last ten years. This expression can be defined in general terms as the desire or excitement of consumers for activities, knowledge acquisition or a product group. In addition, it is closely related to individual values, ego and perceptions of importance ${ }^{22}$. Leisure time involvement is expressed as "the imperceptible state of interest and relation in a recreational activity or by-product, evoked by certain situations and impulses directing the characteristics". Although leisure time involvement in this way is mostly seen as multidimensional structures, in most studies; it is 
stated that there is a positively associated structure with the intensity of involvement, duration of involvement, frequency of involvement and with activity ${ }^{4,20}$. In order to define life satisfaction, it would be more appropriate to explain the word "satisfaction" first. According to Budak (2003), satisfaction is the state of the organism's reaching its former balance after meeting the psychological (curiosity, love, success) or physiological (sexuality, thirst, hunger) needs.

Life satisfaction is one of the most striking factors affecting the mental health and social ties of the person ${ }^{3}$. The concept of life satisfaction can be both handled at a level such as satisfaction from certain areas of life, and it can also be examined for a large part of life. In other words, it is how much an individual is satisfied with his/her own life, and this term expresses positive feelings about life. Life satisfaction is the level of positive evaluation of one's own life as a whole ${ }^{14}$. Güllüoğlu-Işık and Koçak (2014) define life satisfaction, related to the happiness of the individual and constitutes a very important place in the literature of positive psychology, as a person's handling of the quality of life within the framework of his own criteria. Satisfaction is the state of being positive in needs, expectations, wishes and desires. The concept of "satisfaction with life" is the situation or result reached by comparing what a person wants with what $\mathrm{s} /$ he has. In other words, we can say that the result obtained by comparing the expectations of the individual from life with the situation $s /$ he lives in is life satisfaction $^{32}$. Life satisfaction is a process in which a person generally reviews her/his life according to the criteria $\mathrm{s} /$ he has chosen ${ }^{10}$. Life satisfaction is the cognitive component of personal well-being. Life satisfaction can be defined as a comprehensive mental evaluation of one's own life ${ }^{43}$. Although the concept of life satisfaction is encountered many times in our lives, it has been used in more than one sense and a common definition has not been made. Some researchers consider life satisfaction as subjective well-being and some researchers as happiness ${ }^{32}$. General well-being, namely life satisfaction, which is the cognitive component of subjective well-being; It can be divided into satisfactions in some areas of life such as love, friendship, leisure, marriage, and work, and these areas can also be divided into original emotions and mood states such as delightfulness, pleasure, pleasant feeling, pride, honor, and unpleasant feelings, anger guilt, sadness, anxiety, shame etc. ${ }^{43}$. In the literature, it has been observed that people with a high level of life satisfaction have a psychological-social-physically healthy life, more positive relationships and functionality in their social lives, a character compatible with their lives, and a mental structure open to personal development ${ }^{10}$. In addition, it is known that people with positive feelings and thoughts about their lives solve problems better and are more resilient in coping with stress ${ }^{24}$. In the light of all this information, it has been a matter of curiosity whether there is a significant relationship between individuals' interest in recreational activities and their life satisfaction. This research will contribute to the literature in terms of choosing the right leisure time activity, understanding the importance of leisure time activities in increasing interest and life satisfaction.

\section{MATERIAL \& METHODS}

In this research relational screening model, one of the quantitative research approaches.

Sample and Population: The population of the research consisted of individuals who were members of private sports and fitness centers in Kastamonu, Samsun and Hatay provinces. And the sample of the study consists of 450 people $(54.9 \%$ Female, $45.1 \%$ Male) who are members of 6 centers with permission from these centers and voluntarily participated in the research.

Table 1. Distribution of the participants by gender, age, education level, weekly frequency of use, time spent daily

\begin{tabular}{|l|l|l|l|}
\hline Variables & & $\mathrm{N}$ & $\%$ \\
\hline \multirow{2}{*}{ Gender } & Female & 247 & 54,9 \\
& Male & 203 & 45,1 \\
\hline \multirow{4}{*}{ Age } & 20 years and under & 72 & 16 \\
& $21-30$ & 198 & 44 \\
& $31-40$ & 149 & 33,1 \\
& 41 and above & 31 & 6,9 \\
\hline Educational & High school and earlier & 220 & 48,9 \\
status & University and postgraduate & 230 & 51,1 \\
\hline Frequency of & 1-2 days & 62 & 13,8 \\
use per week & $3-4$ days & 338 & 75.1 \\
& 5 days or more & 50 & 11,1 \\
\hline Time spent & 1 hour or less & 106 & 23,6 \\
daily & 2 hours & 262 & 58,2 \\
& 3 hours or more & 82 & 18,0 \\
\hline
\end{tabular}

Data Collection Tools: In order to determine the leisure time involvement levels of the participants, Leisure Involvement Scale (LIS) was used, developed by Kyle et al. (2007), Gürbüz et al. (2015), whose validity and reliability for Turkish culture was made. The scale consists of 15 items and 5 sub-dimensions (attraction, caring, social relationship, identification and self-expression). The leisure involvement scale is a 5-point Likert (1. I strongly disagree 2. I disagree 3. I am undecided 4. I agree 5. I strongly agree). Also, Life Satisfaction Scale (LSS) developed by Diener et al. (1985) and adapted to Turkish culture by Köker (1991), was used. The scale consists of one dimension and 5 items and a 7-point Likert scale. (1. Strongly disagree. 2. Disagree. 3. Slightly disagree. 4. Neither agree nor disagree. 5. Agree slightly. 6. Agree. 7. Strongly agree)

Data analysis: SPSS package was used in data analysis. For determining whether the data had a normal distribution or not, 'Kolmogorov-Smirnov' test were used and 'AnovaHomogenety of variance" test were used for the homogeneity of data and as a result of these tests the data were determined to have a normal distribution and a homogeneity. Descriptive statistics (percentage, requency, standard deviation, etc.), Independent Sample t-test, ANOVA test and Pearson Correlation test were used in data analysis. The post-hoc Tukey test was used to determine which groups the differences incurred from as a result of the ANOVA test originated. Cronbach Alpha internal consistency coefficients were calculated to test the reliability level of the scales. They were found as Satisfaction with Life Scale $=, 87$, Leisure Involvement Scale sub-dimensions Attractive $=, 73, \quad$ Caring $=75$, social relationship $=, 75$, identification $=, 74$, self-expression $=, 74$. 


\section{RESULTS}

When the mean scores of the participants on the Leisure Involvement Scale (LIS) were examined, it was observed that the sub-dimension with the lowest average was "social relationship", and the sub-dimension with the highest average was "Attractiveness".

When the average score of the Life Satisfaction Scale is examined, it is seen that the average of the LSS is 20.66 and the participants' life satisfaction is high.

Table 2. Mean and standard deviation values of LIS sub-dimensions and LSS scores

Table 2. Mean and standard deviation values of LIS sub-dimensions and LSS scores
\begin{tabular}{|l|l|l|l|l|}
\hline & Sub dimension & N & Mean & SD \\
\hline \multirow{4}{*}{ LIS } & Attractiveness & 450 & 10,0978 & 2,55527 \\
\cline { 2 - 5 } & Caring & 450 & 10,0489 & 2,46622 \\
\cline { 2 - 5 } & Social Relationship & 450 & 9,7378 & 2,55673 \\
\cline { 2 - 5 } & Identification & 450 & 10,0111 & 2,58182 \\
\cline { 2 - 5 } & Expressing yourself & 450 & 10,0467 & 2,56324 \\
\hline LSS Total & 450 & 20,6600 & 5,50945 \\
\hline
\end{tabular}

Table 3. T-test results of the participants' LIS sub-dimensions and LSS scores according to gender variable

\begin{tabular}{|c|c|c|c|c|c|c|c|}
\hline & Sub dimension & Gender & $\mathrm{N}$ & Mean & SD & $\mathrm{T}$ & $\mathrm{P}$ \\
\hline & Attractiveness & $\begin{array}{l}\text { Male } \\
\text { Female }\end{array}$ & $\begin{array}{l}203 \\
247\end{array}$ & $\begin{array}{l}10,3103 \\
9,9231\end{array}$ & $\begin{array}{l}2,63022 \\
2,48372\end{array}$ & 1,594 & ,112 \\
\hline & Caring & $\begin{array}{l}\text { Male } \\
\text { Female }\end{array}$ & $\begin{array}{l}203 \\
247 \\
\end{array}$ & $\begin{array}{l}10,0394 \\
10,0567\end{array}$ & $\begin{array}{l}2,53460 \\
2,41372\end{array}$ &,- 073 & ,941 \\
\hline & Social Relationship & $\begin{array}{l}\text { Male } \\
\text { Female }\end{array}$ & $\begin{array}{l}203 \\
247\end{array}$ & $\begin{array}{l}9,8473 \\
9,6478\end{array}$ & $\begin{array}{l}2,62157 \\
2,50395\end{array}$ & ,820 & ,413 \\
\hline$\frac{\omega}{5}$ & Identification & $\begin{array}{l}\text { Male } \\
\text { Female }\end{array}$ & $\begin{array}{l}203 \\
247 \\
\end{array}$ & $\begin{array}{l}10,0493 \\
9,9798\end{array}$ & $\begin{array}{l}2,71912 \\
2,46842\end{array}$ & ,281 & ,779 \\
\hline & Expressing yourself & $\begin{array}{l}\text { Male } \\
\text { Female }\end{array}$ & $\begin{array}{l}203 \\
247 \\
\end{array}$ & $\begin{array}{l}10,1527 \\
9,9595 \\
\end{array}$ & $\begin{array}{l}2,69053 \\
2,45578 \\
\end{array}$ & ,788 & ,431 \\
\hline LS & S Total & $\begin{array}{l}\text { Male } \\
\text { Female }\end{array}$ & $\begin{array}{l}203 \\
247\end{array}$ & $\begin{array}{l}21,0049 \\
20,3765 \\
\end{array}$ & $\begin{array}{l}6,00289 \\
5,06301 \\
\end{array}$ & 1,205 & ,027 \\
\hline
\end{tabular}

Table 4. Anova test results according to the age variable of the participants' LIS sub-dimensions and LSS scores

\begin{tabular}{|c|c|c|c|c|c|c|c|}
\hline \multirow{6}{*}{ LIS } & Sub dimension & Age & $\mathrm{N}$ & Mean & SD & $\mathrm{F}$ & $\mathrm{P}$ \\
\hline & Attractiveness & $\begin{array}{l}20 \text { years and under } \\
21-30 \\
31-40 \\
41 \text { and above }\end{array}$ & $\begin{array}{l}72 \\
198 \\
149 \\
31\end{array}$ & $\begin{array}{l}11,1667 \\
10,1414 \\
9,4430 \\
10,4839 \\
\end{array}$ & $\begin{array}{l}2,61631 \\
2,63136 \\
2,25527 \\
2,43408 \\
\end{array}$ & 8,082 & ,000 \\
\hline & Caring & $\begin{array}{l}20 \text { years and under } 21-30 \\
31-40 \\
41 \text { and above }\end{array}$ & $\begin{array}{l}72 \\
198 \\
149 \\
31\end{array}$ & $\begin{array}{l}10,9167 \\
9,9495 \\
9,7114 \\
10,2903\end{array}$ & $\begin{array}{l}2,47096 \\
2,59196 \\
2,23696 \\
2,29773 \\
\end{array}$ & 4,195 & ,006 \\
\hline & Social Relationship & $\begin{array}{l}20 \text { years and under } 21-30 \\
31-40 \\
41 \text { and above }\end{array}$ & $\begin{array}{l}72 \\
198 \\
149 \\
31\end{array}$ & $\begin{array}{l}10,8333 \\
9,6465 \\
9,2953 \\
9,9032\end{array}$ & $\begin{array}{l}2,44373 \\
2,63638 \\
2,40636 \\
2,35733\end{array}$ & 6,232 & ,000 \\
\hline & Identification & $\begin{array}{l}20 \text { years and under } \\
21-30 \\
31-40 \\
41 \text { and above }\end{array}$ & $\begin{array}{l}72 \\
198 \\
149 \\
31\end{array}$ & $\begin{array}{l}11,1528 \\
9,8687 \\
9,5772 \\
10,3548\end{array}$ & $\begin{array}{l}2,55453 \\
2,64343 \\
2,38572 \\
2,45694\end{array}$ & 6,728 & ,000 \\
\hline & Expressing yourself & $\begin{array}{l}20 \text { years and under } \\
21-30 \\
31-40 \\
41 \text { and above }\end{array}$ & $\begin{array}{l}72 \\
198 \\
149 \\
31\end{array}$ & $\begin{array}{l}11,1806 \\
9,9394 \\
9,6376 \\
10,0645\end{array}$ & $\begin{array}{l}2,53053 \\
2,65941 \\
2,37730 \\
2,20508 \\
\end{array}$ & 6,293 & ,000 \\
\hline \multicolumn{2}{|c|}{ LSS Total } & $\begin{array}{l}20 \text { years and under } \\
21-30 \\
31-40 \\
41 \text { and above }\end{array}$ & $\begin{array}{l}72 \\
198 \\
149 \\
31\end{array}$ & $\begin{array}{l}21,8472 \\
20,5556 \\
20,2483 \\
20,5484 \\
\end{array}$ & $\begin{array}{l}6,80029 \\
5,46279 \\
4,47199 \\
6,77662\end{array}$ & 1,424 & ,235 \\
\hline
\end{tabular}

When Table 3 is examined, it is seen that the arithmetic mean of the leisure time involvement scale in sub-dimensions of "attractive" $(X=10.31)$, "caring" $(X=10.03)$, "social relationship" $(X=9.84)$, "identification" $(X=10.0), 04)$ and "self-expression" $(X=10.15)$ is higher in men than that of women. It was examined with the t-test whether these differences between the groups were statistically significant, and the analysis results of the participants' LIS "attractiveness" ( $\mathrm{t}=1,594)$, "caring" ( $\mathrm{t}=-$ 0.73), "social relationship" ( $\mathrm{t}=, 820)$, "identification" $(\mathrm{t}=, 281)$ and "self-expression" $(\mathrm{t}=, 788 ; \mathrm{p}<0.05)$ sub-dimensions did not differ statistically in favor of men according to the scores they got.

In the Satisfaction with Life Scale, it is seen that the arithmetic mean of men $(X=21.00)$ is higher than that of women. It was examined with the t-test whether these differences between the groups were statistically significant, and the results of the analysis show that there is a statistically significant difference in favor of men according to the scores of the participants in the LSS $(T=1,205 ; p<0.05)$. This situation reveals that men who are interested in fitness in their free time have higher life satisfaction than women.

When Table 4 is examined, it is seen that the leisure time involvement scale is "attractive" $(X=11.16)$, "caring" $(X=10.91)$, "social relationship" $(X=10.83)$, "identification" $(X=11,15)$ and "self-expression" (X=11.18) subdimensions, it is seen that the arithmetic mean of the participants in the 20 and below age group is higher than 
the other age groups. It was examined with the ANOVA test whether these differences between the groups were statistically significant, and the analysis results showed that there is a statistically significant difference according to the scores participants get from the sub-dimensions of the LIS on"attractiveness" $F=8.082 ; \quad p<0.05$, "caring" $F=4.195$; $p<0.05$, "social relationship" $F=6.232$; $p<0.05$, "identification" $F=6.728$; $p<0.05$, "self-expression" $F=6.293$; $\mathrm{p}<0.05)$. As a result of the post-hoc Tukey test after oneway analysis of variance (ANOVA), conducted to determine between which groups the sub-dimension scores of LIS differ according to the age variable, it was found that there was a significant difference in favor of participants aged 20 years and under between participants aged 20 and under and participants aged 21-30 and $31-40$ in all subdimensions. $(p<0.5)$. In the attractiveness sub-dimension, a statistically significant difference was found between the 21-30 and 31-40 age groups in favor of the 21-30 age group. This situation shows that individuals in the age group of 20 and below are more interested in leisure time activities compared to the age groups of 21-30 and 31-40, and participants in the age group of 21-30 are more involved in leisure activities compared to the participants in the age group of $31-40$, and the involvement decreases as the age progresses $(p>0,05)$.

No statistically significant difference was found according to age groups in the life satisfaction scale $(F=1.424 ; p z>0.05)$.

Table 5a. T-test results according to the educational status variable of the participants' LIS sub-dimensions and LSS scores

\begin{tabular}{|c|c|c|c|c|c|c|c|}
\hline \multirow{3}{*}{$\underline{\omega}$} & $\begin{array}{l}\text { Sub } \\
\text { dimension }\end{array}$ & Education & $\mathrm{N}$ & Mean & SD & $T$ & $\mathrm{P}$ \\
\hline & Attractiveness & $\begin{array}{l}\text { High school } \\
\text { and below } \\
\text { University/ } \\
\text { Postgraduate }\end{array}$ & $\begin{array}{l}220 \\
230\end{array}$ & $\begin{array}{l}9,7636 \\
10,4174\end{array}$ & $\begin{array}{l}2,30714 \\
2,73896\end{array}$ & $-2,732$ & ,007 \\
\hline & Caring & $\begin{array}{l}\text { High school } \\
\text { and below } \\
\text { University/ } \\
\text { Postgraduate }\end{array}$ & $\begin{array}{l}220 \\
230\end{array}$ & $\begin{array}{l}9,8864 \\
10,2043\end{array}$ & $\begin{array}{l}2,31351 \\
2,59946\end{array}$ & $-1,372$ & 171 \\
\hline
\end{tabular}

When Table 5 is examined, it is seen that the arithmetic averages of the participants with university/postgraduate education status of the LIS scores on "attractiveness" ( $X=10.41)$, "attention" ( $X=10.20)$, "social relationship" ( $X=10.20)$, "identification" ( $X=10.51)$ and "selfexpression" ( $X=10.34)$ sub-dimensions, are higher than those of the participants with high school and below averages. It was examined with the t-test whether these differences between the groups were statistically significant, and the results of the analysis showed that the participants' LIS scores from sub-dimensions were "attractive" $\quad(\mathrm{t}=-2.732 ; \mathrm{p}<0.05)$, "social relationship" ( $\mathrm{t}=-$ $4,025 ; \mathrm{p}<0,05)$, "identification" $(\mathrm{t}=-4.337 ; \mathrm{p}<0.05)$ and "selfexpression" $(\mathrm{t}=-2.566 ; \mathrm{p}<0.05)$ and that a significant difference in favor of the participants with a university/graduate degree. This situation reveals that the leisure time interests of the individuals with a university/postgraduate education level show more interest in leisure time activities than the participants with a high school or below education level.

When Table 5 is examined, it is seen that the arithmetic averages of the participants with university/postgraduate education level $(X=21,63)$ are higher than the participants with high school or below education level. It was examined with the t-test whether these differences between the groups were statistically significant, and the results of the analysis showed that the scores of the participants in the LSS differed significantly in favor of the participants with a university/postgraduate degree $(t=-3,888 ; p<0.05)$. This situation reveals that the life satisfaction of the participants with university/graduate education status is higher than the other participants.

Table $5 \mathrm{~b}$. T-test results according to the educational status variable of the participants' LIS sub-dimensions and LSS scores

\begin{tabular}{|c|c|c|c|c|c|c|c|}
\hline & Sub dimension & Education & $\mathrm{N}$ & Mean & $\mathrm{SD}$ & $T$ & $\mathrm{P}$ \\
\hline \multirow{3}{*}{$\stackrel{\infty}{=}$} & $\begin{array}{l}\text { Social } \\
\text { Relationship }\end{array}$ & $\begin{array}{l}\text { High school } \\
\text { and below } \\
\text { University/ } \\
\text { Postgraduate }\end{array}$ & $\begin{array}{l}220 \\
230\end{array}$ & $\begin{array}{l}9,2500 \\
10,2043\end{array}$ & $\begin{array}{l}2,54749 \\
2,48260\end{array}$ & $-4,025$ & ,000, \\
\hline & Identification & $\begin{array}{l}\text { High school } \\
\text { and below } \\
\text { University/ } \\
\text { Postgraduate }\end{array}$ & $\begin{array}{l}220 \\
230\end{array}$ & $\begin{array}{l}9,4818 \\
10,5174\end{array}$ & $\begin{array}{l}2,53282 \\
2,53140\end{array}$ & $-4,337$ & ,000 \\
\hline & $\begin{array}{l}\text { Expressing } \\
\text { yourself }\end{array}$ & $\begin{array}{l}\text { High school } \\
\text { and below } \\
\text { University/ } \\
\text { Postgraduate }\end{array}$ & $\begin{array}{l}220 \\
230\end{array}$ & $\begin{array}{l}9,7318 \\
10,3478\end{array}$ & $\begin{array}{l}2,51132 \\
2,58157\end{array}$ & 2,566 & 011 \\
\hline LSS & Total & $\begin{array}{l}\text { High school } \\
\text { and below } \\
\text { University/ } \\
\text { Postgraduate }\end{array}$ & $\begin{array}{l}220 \\
230\end{array}$ & $\begin{array}{l}19,6409 \\
21,6304\end{array}$ & $\begin{array}{l}5,06155 \\
5,75390\end{array}$ & $3,888^{-}$ & ,000 \\
\hline
\end{tabular}

When Table 6 is examined, the LIS scores on "attractiveness" $(X=11.00)$, "attention" $(X=10.32)$, "social relationship" ( $X=10.66)$, "identification" ( $X=11.06)$ and "selfexpression" ( $X=10.84)$ sub-dimensions, it is seen that the arithmetic averages of the participants going to the sports center 5 days or more a week are higher than the other participants. It was examined with the ANOVA test whether these differences between the groups were statistically significant, and the analysis results showed that the participants' LIS scores of "attractiveness" ( $F=3.803$; $p<0.05)$, "caring" ( $F=4.154 ; p<0.05)$, "social relationship" $(F=4,015 ; p<0.05)$ and "identification" $(F=4.765 ; p<0.05)$ sub-dimensions differed significantly in their scores. It has been observed that there is a statistically significant difference as a result of the post-hoc Tukey test after the one-way analysis of variance (ANOVA), which was conducted to determine between which groups the LIS subdimension scores differ according to the frequency of weekly use variable, in the "attractiveness" and "identification" sub-dimensions of the LIS, between the participants going to the sports center 5 days or more a week, compared to the participants who go to the sports center 1-2 days and 3-4 days a week, in favor of the participants going to the sports center 5 days or more a week. $(p<0,05)$. In the sub-dimension of LIS, it was observed that there is a statistically significant difference between the participants going to the sports center 3-4 days a week compared to the participants going to the sports center 1-2 days a week, in favor of the participants going to the sports center 3-4 days a week, and between the participants going to the sports center 5 days or more a week compared to the participants going to the sports center 1-2 days a week, in favor of the participants going to the sports center for 5 days or more per week $(p<0.05)$. In the "social relationship" sub-dimension of the LIS, it was observed that there was a statistically significant difference in favor of the participants going to the sports center 5 days or more a week, compared to the participants going to the sports center 3-4 days a week, in favor of the participants 
going to the sports center 5 days or more per week $(p<0.05)$. This situation reveals that the participants going to the sports center 5 days a week show more interest in leisure activities than the participants going to the sports center 1-2 and 3-4 days a week.

When Table 6 is examined, it is seen that the arithmetic mean $(X=22.92)$ of the participants going to the sports center for 5 days or more a week in LSS is higher than that of the other participants. Whether these differences between the groups were statistically significant was examined with the ANOVA test, and the results of the analysis show that the scores of the participants in the LSS differed significantly $(F=5.062 ; p<0.05)$. It was observed that there was a statistically significant difference, as a result of the post-hoc Tukey test after the one-way analysis of variance (ANOVA), conducted to determine between which groups the LSS scores differ according to the weekly usage frequency variable, the participants going to the sports center 5 days a week compared to the participants going to the sports center 1-2 days a week and 3-4 days a week, in favor of the participants going to the sports center 5 days a week $(p<0.05)$. This shows that the life satisfaction of the participants going to the sports center 5 days a week is higher than the participants going to the sports center 1-2 and 3-4 days a week.

When Table 7 is examined, it is seen that the arithmetic averages of the participants spending 2 hours a day in the sports center in sub-dimension on the "attractiveness" (X=10.22) of the LIS, the participants spending 3 or more hours a day in the sports center in the sub-dimension on "caring" ( $X=10.24)$, "social relationship" $(X=10.52)$ "identification" $(X=2.811)$ and "self-expression" $(X=10.71)$ are higher than those of the other participants. It was examined with the ANOVA test whether these differences between the groups were statistically significant, and the results of the analysis showed that the participants' scores that they got from the sub-dimensions of LIS on "caring" ( $F=3.478 ; p<0.05)$, "social relationship" $(F=5,755 ; p<0.05)$ and "self-expression" $(F=3,795 ; p<0.05)$ differed significantly. It was examined with the ANOVA test whether these differences between the groups were statistically significant, as a result of post-hoc Tukey test after one-way analysis of variance (ANOVA), conducted to determine between which groups the LIS scores differ according to the time spent daily variable, it was observed that there was a statistically significant difference in favor of the participants spending 2 hours a day in the sports center in the "caring" sub-dimension of the LIS, compared to the participants spending 1 hour or less in the sports center per day $(p<0,05)$. On the other hand, in the sub-dimensions of "social relationship" and "self-expression", a significant difference was observed between the participants spending 3 hours or more in the sports center are statistically in favor of the participants spending 3 hours or more, compared to the participants spending 1 hour or less a day and 2 hours a day in the sports center $(p<0.05)$. This situation reveals that the participants spending 3 or more hours a day at the sports center have higher levels of involvement than the participants spending 1 hour or less and 2 hours a day at the sports center, and the participants spending 2 hours a day at the sports center have a higher level of involvement than the participants spending 1 hour or less per day.

When Table 7 is examined, it is seen that the arithmetic averages of the participants spending 2 hours a day in the sports center are higher than those of the other participants $(X=20.99)$. Whether these differences between the groups were statistically significant was examined with the ANOVA test, and the results of the analysis show that the scores of the participants in the LSS did not differ significantly ( $p>0.05)$.

When Table 8 is evaluated, according to the result of the correlation analysis performed to show the relationship between "leisure time involvement and life satisfaction"; "caring" ( $p=.476, p<0.00)$, "social relationship" $(p=.470$, $p<0.00)$ "identification" $(p=.570, p<0.00)$ life satisfaction , "self-expression" ( $p=, 542, p<0.00)$ and "attractiveness" $(p=$ ,452, $p<0.00$ ) dimensions were found to have a low and positive relationship.

Table 6. The Anova test results according to the frequency of weekly use of the participants' LIS and LSS scores

\begin{tabular}{|c|c|c|c|c|c|c|c|}
\hline & Sub dimension & $\begin{array}{l}\text { Frequency } \\
\text { of use } \\
\text { per week }\end{array}$ & $\mathrm{N}$ & Mean & SD & $\mathrm{F}$ & $\mathrm{P}$ \\
\hline \multirow[b]{5}{*}{$\underline{O}$} & Attractiveness & $\begin{array}{l}\text { 1-2 days } \\
3-4 \text { days } \\
5 \text { days } \\
\text { and more }\end{array}$ & $\begin{array}{l}62 \\
338 \\
50\end{array}$ & $\begin{array}{l}9,7742 \\
10,0237 \\
11,0000\end{array}$ & $\begin{array}{l}2,12263 \\
2,39919 \\
3,69224\end{array}$ & 3,803 & ,023 \\
\hline & Caring & $\begin{array}{l}\text { 1-2 days } \\
3-4 \text { days } \\
5 \text { days } \\
\text { or more }\end{array}$ & $\begin{array}{l}62 \\
338 \\
50\end{array}$ & $\begin{array}{l}9,2258 \\
10,1598 \\
10,3200\end{array}$ & $\begin{array}{l}2,33589 \\
2,35775 \\
3,11311\end{array}$ & 4,154 & ,016 \\
\hline & Social Relationship & $\begin{array}{l}1-2 \text { days } \\
3-4 \text { days } \\
5 \text { days } \\
\text { or more }\end{array}$ & $\begin{array}{l}62 \\
338 \\
50\end{array}$ & $\begin{array}{l}9,8548 \\
9,5799 \\
10,6600\end{array}$ & $\begin{array}{l}2,21653 \\
2,53658 \\
2,91099\end{array}$ & 4,015 & ,019 \\
\hline & Identification & $\begin{array}{l}1-2 \text { days } \\
3-4 \text { days } \\
5 \text { days } \\
\text { or more }\end{array}$ & $\begin{array}{l}62 \\
338 \\
50\end{array}$ & $\begin{array}{l}9,7903 \\
9,8964 \\
11,0600\end{array}$ & $\begin{array}{l}2,35488 \\
2,50541 \\
3,11946\end{array}$ & 4,765 & ,009 \\
\hline & Expressing yourself & $\begin{array}{l}1-2 \text { days } \\
3-4 \text { days } \\
5 \text { days } \\
\text { or more }\end{array}$ & $\begin{array}{l}62 \\
338 \\
50\end{array}$ & $\begin{array}{l}9,8548 \\
9,9645 \\
10,8400\end{array}$ & $\begin{array}{l}2,2092 \\
2,51498 \\
3,14519\end{array}$ & 2,764 & ,064 \\
\hline \multicolumn{2}{|c|}{ LSS Total } & $\begin{array}{l}\text { 1-2days } \\
3-4 \text { days } \\
5 \text { days } \\
\text { or more }\end{array}$ & $\begin{array}{l}62 \\
338 \\
50\end{array}$ & $\begin{array}{l}19,9355 \\
20,4556 \\
22,9200\end{array}$ & $\begin{array}{l}6,16939 \\
4,90256 \\
7,71122\end{array}$ & 5,062 & ,007 \\
\hline
\end{tabular}


Table 7. Anova test results according to the time spent daily variable of the participants' LIS and LSS scores

\begin{tabular}{|c|c|c|c|c|c|c|c|}
\hline & Sub dimension & Time spent daily & $\mathrm{N}$ & Mean & SD & $\mathrm{F}$ & $\mathrm{P}$ \\
\hline & Attractiveness & $\begin{array}{l}1 \text { hour or less } \\
2 \text { hours } \\
3 \text { hours or more }\end{array}$ & $\begin{array}{l}106 \\
262 \\
82 \\
\end{array}$ & $\begin{array}{l}9,7075 \\
10,2214 \\
10,2073\end{array}$ & $\begin{array}{l}2,15569 \\
2,44413 \\
3,26500\end{array}$ & 1,622 & , 199 \\
\hline$\frac{\omega}{J}$ & Caring & $\begin{array}{l}1 \text { hour or less } \\
2 \text { hours } \\
3 \text { hours or more }\end{array}$ & $\begin{array}{l}106 \\
262 \\
82 \\
\end{array}$ & $\begin{array}{l}9,5000 \\
10,2099 \\
10,2439\end{array}$ & $\begin{array}{l}2,28557 \\
2,35495 \\
2,92525\end{array}$ & 3,478 & ,032 \\
\hline
\end{tabular}

\begin{tabular}{|c|c|c|c|c|c|c|}
\hline Social Relationship & $\begin{array}{l}1 \text { hour or less } \\
2 \text { hours } \\
3 \text { hours or more }\end{array}$ & $\begin{array}{l}106 \\
262 \\
82\end{array}$ & $\begin{array}{l}9,2830 \\
9,6756 \\
10,5244\end{array}$ & $\begin{array}{l}2,24989 \\
2,51998 \\
2,88130\end{array}$ & 5,755 & ,003 \\
\hline Identification & $\begin{array}{l}1 \text { hour or less } \\
2 \text { hours } \\
3 \text { hours or more }\end{array}$ & $\begin{array}{l}106 \\
262 \\
82\end{array}$ & $\begin{array}{l}2,23522 \\
2,63477 \\
2,81115\end{array}$ & $\begin{array}{l}2,23522 \\
2,63477 \\
2,81115\end{array}$ & 1,229 & ,294 \\
\hline Expressing yourself & $\begin{array}{l}1 \text { hour or less } \\
2 \text { hours } \\
3 \text { hours or more }\end{array}$ & $\begin{array}{l}106 \\
262 \\
82 \\
\end{array}$ & $\begin{array}{l}9,7358 \\
9,9618 \\
10,7195 \\
\end{array}$ & $\begin{array}{l}2,30652 \\
2,58319 \\
2,72290 \\
\end{array}$ & 3,795 & ,023 \\
\hline LSS Total & $\begin{array}{l}1 \text { hour or less } \\
2 \text { hours } \\
3 \text { hours or more }\end{array}$ & $\begin{array}{l}106 \\
262 \\
82 \\
\end{array}$ & $\begin{array}{l}20,1226 \\
20,9962 \\
20,2683\end{array}$ & $\begin{array}{l}5,25303 \\
5,43121 \\
6,05336\end{array}$ & 1,199 & ,302 \\
\hline
\end{tabular}

Table 8. Analysis of Correlations between LIS and LSS

\begin{tabular}{|c|c|c|c|c|c|c|}
\hline & 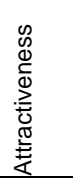 & 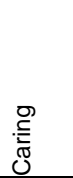 & 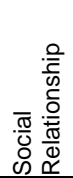 & 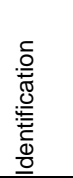 & 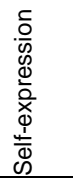 & 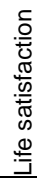 \\
\hline Attractiveness & 1 & & & & & \\
\hline Caring &, $476^{*}$ & 1 & & & & \\
\hline Social Relationship & $470^{*}$ & $450^{*}$ & 1 & & & \\
\hline Identification &, $570^{*}$ &, $447^{*}$ &, $474^{*}$ & 1 & & \\
\hline Self-expression &, $542^{*}$ & $496^{\star}$ & $483^{*}$ &, $566^{*}$ & 1 & \\
\hline Life satisfaction &, $452^{*}$ & $384^{*}$ & $329^{*}$ &, $387^{*}$ & ,359* & 1 \\
\hline
\end{tabular}

\section{DISCUSSION}

According to the research data conducted to determine the level of involvement and life satisfaction of individuals who are members of fitness centers for recreational activities; it is seen that $55 \%$ of the participants were women, $44 \%$ were between the ages of $21-30,49 \%$ were high school graduates and earlier, $75 \%$ went to the sports center 3-4 days a week, $58 \%$ of them spend 2 hours a day at the sports center. When the sub-dimensions of LIS are examined, when the mean scores of LIS in the dimensions of "attractiveness", "caring", "social relationship", "identification" and "self-expression" are examined, it was determined that the sub-dimension with lowest average was "social relationship", the sub-dimension with the highest average was "attractiveness". Considering the subdimension with a high average, it can be said that it is a natural finding that the fitness activity is perceived as more "attractive" by the members, as it allows the members to have a more muscular and fit body as desired. Considering the sub-dimension that the members have a low average in the study, it can be said that the average of this subdimension is low because the members give importance to the shape of their bodies, that is, to their appearance, rather than their thoughts such as socializing and making friends in fitness activities. In addition, when the average score of LSS is examined, it is seen that the average of LSS is 20.66 and the life satisfaction of the participants is high. As a matter of fact, recreational activities have an important place in people's lives to be happy and/or to achieve life satisfaction ${ }^{1}$. In the research conducted by Özel (2019) on university students participating in recreational activities, it was determined that participation in recreational activities has a positive effect on life satisfaction.

Although there is no significant difference in all subdimensions of LIS according to the gender of the participants, it is seen that the arithmetic mean of men is higher than that of women in all sub-dimensions. Although there was no significant difference in our study, it can be said that the gender variable shows an important distinguishing feature in leisure time involvement ${ }^{4}$. In the study of Wiley et al. (2000), a significant difference was found in the self-expression sub-dimension of female hockey players, which is one of the sub-dimensions of LIS. In Aydin (2016)'s study in which he examined the involvement levels of fitness center members, although the main effect of the gender variable on LIS sub-dimensions was not significant, it was determined that in the dimensions of "attractiveness", "caring", "social relationship" men did; in the dimensions of "identification" and "self-expression" women had high mean values. It can be explained by the fact that men's level of involvement is higher than women's, and due to their social roles in Turkish society, as a result of men's doing less housework, childcaring, etc. than women, they have more free time, that women cannot spare time for recreational activities compared to men due to business life and housework, that their priorities are different, and men can participate in recreational activities more comfortably and easily than women.

According to the gender of the participants, it is seen that the arithmetic averages of men are significantly higher than that of women in the LSS. This can be explained by the fact that more men prefer fitness activities and the 
majority of men participating in fitness activities want to have a physically muscular appearance, so their life satisfaction is higher than women. When the literature is examined, significant differences have been determined mainly between gender and life satisfaction, and they have interpreted this situation by considering factors such as cultural and traditional structure, unemployment rate, living problems, social status of women $3,8,9,25,27,12,34,36,40$. In some studies, it has been concluded that women's life satisfaction is higher than men ${ }^{13,18,29,31}$. These findings do not match with the results of our study. Although it is stated that gender is an important variable in life satisfaction, there are also studies that do not find a significant difference ${ }^{17,21,7}$. It is seen that there is a main effect on the sub-dimensions of LIS according to the age groups of the participants, and the arithmetic mean of the group aged 20 and below in all sub-dimensions is more leisure time involvement than other age groups. This is due to the fact that individuals aged 20 and under choose Fitness as a leisure time activity because they have difficulty in establishing social relationships and Fitness is attractive, thus giving more importance to the activity, wanting to establish a better social relationship thanks to the activity and expressing themselves better and it may be because they feel the need. In our study, it is seen that as age increases, leisure time involvement decreases. The research conducted by Kocaer (2019), on the other hand, shows that as the age increases, leisure time involvement increases. This research does not show parallelism with the research conducted. It was determined that there was no difference in the mean scores of the participants according to the age groups of the LSS. This may be due to the fact that the majority of the members participating in our study were close to each other in age. In Önmen's (2021) study, examining the life satisfaction levels of individuals exercising for recreational purposes, it was found that there is a U-shaped relationship between age and life satisfaction, and that the life satisfaction of young and old people is higher than those of middle age. In the study of Başaran et al. (2019), it was determined that the level of life satisfaction of the mature age group was higher than the younger age group. This situation has been interpreted as being more idealistic and having higher expectations at a young age, while happiness and enjoying life become more prominent in later ages.

In the sub-dimensions of "attractiveness", "social relationship", "identification" and "self-expression" of LIS, it is seen that the arithmetic averages of the participants with university/postgraduate education status are significantly higher than those of the participants with high school and below. This situation can be explained by the fact that individuals with university/postgraduate education status have higher leisure time interests than participants with high school or below education level, and the interest in leisure time activities increases with the increase in the value given to recreational activities as the education level increases. In the studies conducted by Havitz et al. (2013) and Yetim (2014), it was determined that the level of education is a determining variable, and it was concluded that the level of involvement increases as the level of education increases. In the study of Aydın and Yaşartürk (2016) in which they examined the leisure time involvement levels of fitness participants, it was determined that individuals who graduated from high school in all subdimensions of LIS have a higher value than those who are university graduates. The finding of this study differs from our research finding. It has been determined that there is a significant difference in LSS according to education level. It is seen that the life satisfaction of the participants with university/postgraduate education status is higher than the other participants. It can be said that this situation stems from the fact that university life has more social and human relations, as well as the competence to participate in activities that they will enjoy more.

In the sub-dimensions of "attractiveness" and "identification" of LIS, it is seen that the arithmetic averages of the participants going to the sports center 5 days or more per week are significantly higher than those of the participants going to the sports center 1-2 days a week and 3-4 days a week. In the sub-dimension of the LIS, the arithmetic averages of the participants going to the sports center 3-4 days a week are higher than that of the participants going to the sports center 1-2 days a week, and the participants going to the sports center 5 days or more a week than those going to the sports center 1-2 days a week appear to be significantly higher. This can be explained by the fact that the more the frequency of use of the sports center increases, the more identification with the activity or exercise increases, and therefore the importance given to the activity increases and the activity becomes attractive. In the "social relationship" sub-dimension of LIS, it is seen that the arithmetic averages of the participants going to the sports center 5 days or more a week are significantly higher than those of the participants going to the sports center 3-4 days a week. This can be explained by the fact that the participants going to the sports center 5 days a week can find more time to establish social relations because the frequency of use of the sports center is higher. In the study of Aydın and Yaşartürk (2016), in which they examined the involvement levels of fitness participants, it was found that the main effect of weekly use frequency on LIS sub-dimensions was significant, in the sub-dimension scores of "attractiveness", "caring" and "social relationship" of LIS, it was determined that the level of involvement of people going to fitness centers for 5 days or more was higher than other groups. This situation shows that as the level of involvement increases, the frequency of individuals' participation in these activities also increases ${ }^{2}$. This research is similar to our research. According to the frequency of use of the sports center in LSS, it is seen that the arithmetic averages of the participants going to the sports center 5 days or more per week are significantly higher than those of the other participants. This can be explained by the fact that the participants going to the sports center 5 days a week feel better thanks to the activity, and therefore their joy of life and life satisfaction increase.

According to the variable of time spent per day in the sub-dimension of LIS, the arithmetic mean of the participants spending 2 hours a day in the sports center is higher than that of the participants spending 1 hour or less in the sports center in the sub-dimensions of "social relationship" and "self-expression". It is seen that the participants spending 3 hours or more in the sports center 
are significantly higher than the participants spending 1 hour or less per day and 2 hours per day in the sports center. In other words, as the time spent daily in the sports center increases, the importance given to the activity by the participants increases, and their ability to establish social relationships and express themselves increases. In other words, as individuals spend daily on activities, their level of involvement increases. In the study of Aydın and Yaşartürk (2016), a significant difference was found in the subdimensions of "attractiveness", "caring", "social relationship" and "identification" of LIS, according to the time spent daily. In the sub-dimension of "attractiveness", the level of involvement of those who exercised for 2 hours and in the other sub-dimensions of individuals who exercised for 3 hours or more were higher than the other groups. No significant difference was found according to the variable of time spent daily in LSS.

In our study, it was determined that there was a low and positive relationship between the leisure time involvement of the participants and their life satisfaction. Therefore, it is seen that individuals' interest in recreational activities in their free time also positively affects their life satisfaction. It can be said that leisure time activities increase feelings such as happiness, entertainment, success and pleasure, so life satisfaction will increase with such activities ${ }^{39}$. As a matter of fact, in the study of Başaran et al. (2019) on the life satisfaction of fitness center members, they revealed that exercising has a positive effect on the life satisfaction of fitness center members.

\section{CONCLUSION}

As a result, the attractiveness factor has the strongest effect on individuals' leisure time involvement. In addition, it can be said that individuals who do recreational activities in fitness centers have high life satisfaction and the higher their life satisfaction level is, the more positive their level of involvement will become.

\section{REFERENCES}

1. Ardahan, F., \& Turgut, T. (2013). Profiles of those engaged in recreational fishing and hunting: a comparison of hunting awareness levels of these individuals according to various demographic variables. International Journal of Human Sciences, 10(1), 1550-1566.

2. Aydın, İ., \& Yaşartürk, F. (2016). Involvement levels of fitness participants towards recreational activities: status according to demographic characteristics. International Journal of Science Culture and Sport, 4(3), 704-711.

3. Aydıner, B. B. (2011). Examining the sub-dimensions of university students' life goals according to general selfefficacy, life satisfaction and various variables [Unpublished master's thesis]. Sakarya University.

4. Aydin, I. (2016). Determination of interest and happiness levels of fitness participants towards recreational activities [Unpublished Master's Thesis]. Gazi University.

5. Başaran, Z., Doğanay, M., Çolak, S., \& Erdal, R. (2019, April 25-28). Examination of exercise addiction, happiness and life satisfaction of fitness center members in terms of personal characteristics [Conference presentation]. 2nd International Congress of Sports and Wellness for All, Alanya, Antalya.

6. Budak, S. (2003). Psychology Dictionary, Ankara. Science and Art Publications.

7. Busing, K., \& West, C. (2016). Determining the Relationship
Between Physical Fitness, Gender, and Life Satisfaction. SAGE Open, 6 (4), 1-5.

8. Cenkseven, F. (2004). Examining the predictors of subjective and psychological well-being in university students [Unpublished doctoral thesis]. Çukurova University.

9. Deniz, M. \& Yılmaz, E. (2004, July). The relationship between emotional intelligence abilities and life satisfaction of university students [Conference presentation]. XIII. National Educational Sciences Congress, İnönü University, Malatya.

10. Diener, E. (1984). Subjective well-being. Psychological Bulletin, 95(3), 542-575.

11. Diener, E., Emmons, R. A., Larsen, R. J., \& Griffin, S. (1985). The satisfaction with life scale. Journal of Personality Assessment, 49(1), 71-75.

12. Dindar, M.D. \& Bilir-Güler, S. (2019) "The effect of sports activities on company employees", Nobel Scientific Works, Ankara.

13. Gençay, S. (2009). Examination of hopelessness and life satisfaction of physical education teacher candidates in terms of some variables. Electronic Journal of Social Sciences, 8(27), 380-388.

14. Göker, Y. (2013). Examination of the attitudes of foreign university students studying in Turkey towards their life satisfaction and seeking psychological help [Unpublished Master's Thesis]. Gazi University.

15. Güllüoğlu-Işık, O. \& Koçak, Ö. F. (2014). Investigation of life satisfaction of communication faculty students in terms of different variables. Selçuk Communication, 8(3), 281-300.

16. Gülsoy, T. (1999). Dictionary of English-Turkish advertising terms and concepts with Turkish-English index. Adam Publications.

17. Gündoğar, D., Gül, S. S., Uskun, E., Demirci, S., \& Keçeci, D. (2007). Examination of the factors predicting life satisfaction in university students. Clinical Psychiatry, 10(1), 14-27.

18. Güner, N. (2019). The relationship between school administrators' favoritism behaviors and teachers' life satisfaction [Unpublished Master's Thesis]. Dicle University.

19. Gürbüz, B., Çimen, Z., \& Aydın, G. (2015, November 5-7). The validity and reliability study of the Turkish form of the leisure involvement scale [Conference presentation]. III Recreation Research Congress, Eskişehir.

20. Havitz, M.E., Kaczynski, A.T., \& Mannell R.C. (2013). Exploring relationships between physical activity, leisure activity, self-efficacy, and motivation via participant segmentation. Leisure Sciences: An Interdisciplinary Journal, 35(1), 45-62.

21. Hintikka, J. (2001). Religious attendance and life satisfaction in the finnish general population. Journal of Psychology and Theology, 29 (2), 158.

22. Jamrozy, U., Backman, S.J. \& Backman, K.F. (1996). "Involvement and opinion leadership in tourism". Annas of Tourism Research, 23(4), 908-924.

23. Kocaer, G. (2019). Investigation of the relationship between physical education and sports teachers and candidates' attitudes towards teaching profession, leisure time involvement and benefit levels for recreational activities (Bartın province sample) [Unpublished master's thesis] Bartın University.

24. Koçak, O.F. (2016). The relationship between interpersonal conflicts and life satisfaction: A study on university students. International Journal of Social Studies, 9(43), 1956.

25. Koker, S. (1991). Comparison of life satisfaction levels of normal and problematic adolescents [Unpublished Master's Thesis]. Ankara University.

26. Krugman, H. E. (1966). The measurement of advertising involvement. Public Opinion Quarterly, 30(4), 583-596.

27. Kulaksızoğlu, A., \& Topuz, C. (2014). Subjective well being levels of university students. Journal of Educational and 
Instructional Studies in The World, 4(3), 25-34

28. Kyle G.T., Absher J., Norman, W., Hammit, W., \& Jodice, L. (2007). Modified involvement scale. Leisure Studies, 26(4), 398-427.

29. Makas, S. (2019). Investigation of life satisfaction in terms of expressing emotions, resilience and perceived social support [Unpublished Master's Thesis]. Sakarya University.

30. Odabaşı, Y. \& Barış, G. (2003). Consumer behavior. Mediacat Academy.

31. Özel, B. (2019). Investigation of the relationship between university students' levels of life satisfaction, content and self-esteem for recreational activities [Unpublished master's thesis]. Bartın University.

32. Özer, M. \& Karabulut, Ö. Ö. (2003). Life satisfaction in the elderly. Geriatrics. 6(2), 72-74.

33. Özmen, H. (2021). Investigation of happiness levels and life satisfaction of individuals exercising for recreational purposes [Unpublished Master's Thesis]. Necmettin Erbakan University.

34. Reisoğlu, S. (2014). The role of five factors personality traits, humor styles and emotional intelligence in predicting the subjective well-being of university students [Unpublished doctoral dissertation]. Karadeniz Technical University.

35. Tezcan, M. (1982). Evaluation of free time. Ankara University Educational Sciences Publications.

36. Tuzgöl-Dost, M. (2007). Examination of university students' life satisfaction according to some variables. Pamukkale University Faculty of Education Journal, 22(22), 132-143.

37. Uztuğ, F. (2003). Talk as much as your brand! brand communication strategies. MediaCat Academy.

38. Wiley, C.G.E., Shaw, S.M. \& Havitz, M.E. (2000). Men's and women's involvement in sports: an examination of the gendered aspects of leisure involvement. Leisure Sciences: An Interdisciplinary Journal, 22(1), 19-31.

39. Yaşartürk, F., Akyüz, H., \& Karataş, İ. (2017). Investigation of the relationship between the perception of boredom in leisure time and life satisfaction levels of university students participating in recreational activities. International Journal of Cultural and Social Studies, 3 (Special Issue), 239-252.

40. Yavuz-Güler, Ç. \& İşmen-Gazioğlu, A. S. (2008). Subjective well-being, psychiatric symptoms and some personality traits in guidance and psychological counseling students: A comparative study. Dokuz Eylül University Buca Education Faculty Journal, 23, 107-114.

41. Yetim, G. (2014). The effect of leisure involvement on leisure satisfaction and loyalty: A research on fitness centers in Eskişehir [Unpublished Master's Thesis]. Anadolu University.

42. Yetim, G., \& Argan, M. (2018). The relationship between leisure involvement factors and satisfaction and loyalty to the fitness center. Anadolu University Journal of Social Sciences, 18(1), 49-62.

43. Yetim, U. (2001). Pictures of Happiness from Society to Individual. Context Publications.

44. Yönet, E. (2018). Investigation of high school students' sportive leisure time involvement, digital game addiction and quality of life levels. [Unpublished PhD Thesis]. Sakarya University. 